\title{
Erratum to: Editorial: Do Orthopaedic Surgeons Belong on the Sidelines at American Football Games?
}

\author{
Seth S. Leopold MD, Matthew B. Dobbs MD, Mark C. Gebhardt MD, \\ Terence J. Gioe MD, Clare M. Rimnac MD, Montri D. Wongworawat MD
}

Published online: 18 September 2017

(C) The Association of Bone and Joint Surgeons( 2017

\section{Erratum to: Clin Orthop Relat Res \\ DOI 10.1007/s11999-017-5483-6}

In the November Editorial, "Editorial: Do Orthopaedic Surgeons Belong on the Sidelines at American Football Games?" a statistic was attributed to a JAMA study (Ref. 10) that should have been attributed to an article from the New York Times (Ref. 16). The sentence in question should read: "We accept that critique, provided that the skeptics acknowledge that the best-case estimate in support of the safety of football would result in a CTE prevalence estimate of $9 \%$, since only another 1200 ex-NFL players have died [16] since this research group [10] began studying football players' brains."

The authors apologize for the error.

The online version of the original article can be found under doi:10. 1007/s11999-017-5483-6.

S. S. Leopold ( $\bowtie)$, M. B. Dobbs, M. C. Gebhardt, T. J. Gioe, C. M. Rimnac, M. D. Wongworawat

Clinical Orthopaedics and Related Research $\AA$, 1600 Spruce St.,

Philadelphia, PA 19103, USA

e-mail: sleopold@clinorthop.org 